\title{
NEW OR LITTLE KNOWN CALIFORNIAN ORTHOPTERA.
}

By SAMUEL H. SCUDDER, CAMBRIDGE, MASS.

The species here brought together were most of them collected by Mr. A. P. Morse, in the summer of 1897 , and as they belong to miscellaneous genera, none of which require special revision, the descriptions are here collected for publication.

\section{Loboptera americana Scudd.}

The single original specimen of this species was taken in Arizona, and was apparentily collected in alcohol, as two fresh specimens taken by Mr.

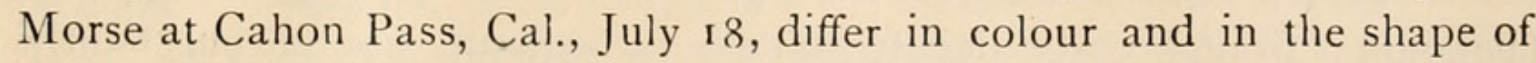
the pronotum, requiring its partial re-description. The pronotum is fusco-castaneous, only less obscure than the abdomen, very faintly and delicately mottled with luteo-castaneous; it has no mesial constriction (due in the original specimen to contraction in drying), but a regular parabolic curve, and is feebly margined laterally. The tegmina are castaneous, either with the inner half fuscous or with a fuscous median streak. The antennæ are of the length of the body, fusco-luteous. gradually becoming paler distally, very sparsely and delicately verticillate. The legs are uniform luteo-castaneous, the spines concolorous. The form of the whole body is not so oval as indicated in the original figure, but nearly parallel-sided, the abdomen with an independent fullness, and both extremities, but especially the posterior, broadly rounded. The figure also represents the legs as stouter and shorter than they are.

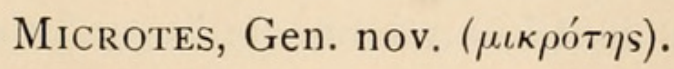

Allied to Spharagemon and Tomonotus. Moderately robust, but of small size. Head normal, the summit without carination; fastigium of vertex oval, rather deeply impressed, completely margined with elevated walls; lateral foveolæ triangular, a little elongate, but not reaching the tip of the vertical fastigium; frontal costa not very broad, deeply sulcate, subequal but enlarging below; eyes rather small and prominent; antennæ rather coarse, not tapering, blunt-tipped, in the male only a little longer than the head and pronotum together. Pronotum moderately stout, mesialiy compressed, the median carina moderately high, cut only by the principal sulcus, the lateral canthi distinct, distinctly cut by the principal sulcus and fading in advance of it, the process of the metazona subrectangulate; interspace between both mesosternal and metasternal lobes distinctly transverse in both sexes. 
Tegnina moderately broad, the intercalary vein straight, approximate to the median vein ; wings crossed by an extramesial fuscous band, cloudy below the humeral field and in that field sending a tænia nearly to the base. Hind femora rather broad, the inferior carina less elevated than the superior, not very arcuate.

The following single species is known to me:

\section{Microtes nubila, sp. nov.}

Fuscous or cinereo-fuscous. Head ferrugineo-fuscous blotched with cinereous, the summit more or less rugulose behind the deep and smooth fastigium; frontal costa deeply sulcate throughout, not or but faintly expanded at the ocellus; antennæ fusco-ferruginous, punctate, considerably less than half as long as the tegmina. Pronotum fuscous or ferrugineofuscous blotched with cinereous, the lateral lobes with a small central bright quadrate spot, the disc rugulose or granulate, with no defined direction to the independent rugæ, the median carina moderately high and subequal on the prozona, though somewhat sinuate on a lateral view, gradually lowering on the metazona. Tegmina cinereous, crossed by rather broad, often broken, fuscous bands, a broad basal one, a mesial and a generally shattered extramesial one, the cinereous clouds on either side the median fuscous band hardly crossing the wing, but clear and distinct on the costal border, the whole anal area uniform fusco-cinereous; wings hyaline, weakly tinged with citron basally, the humeral field with a longitudinal fusco-fuliginous stripe occupying the basal half and a similar costal stigma, the anal field feebly infumate beyond the middle, especially in a rather narrow transverse extramesial band, which attains but does not follow the hind margin. Hind femora cinereo-testaceous, four times narrowly and obliquely banded with fuscous; hind tibiæ glaucous, with the base black and a postbasal luteous annulus.

Length of body, of, $14.5 \mathrm{~mm}$., $q$, 2I mm.; antennæ, of, $6 \mathrm{~mm}$; tegmina, $f$, I $5 \mathrm{~mm}$., $q$, $19.5 \mathrm{~mm}$.; hind femora, of, $10 \mathrm{~mm}$., $q$, $13 \mathrm{~mm}$.

4 f , r $q$. Monterey, Cal., July 16. R. W. Doane (Mus. Leland Stanford Jr. University).

Trimerotropis gratiosa, sp. nov.

Allied to $T$. pacifica. Robust, cinereo-testaceous, rather feebly marked with fuscous. Head as in $T$. pacifica, with rather more pronounced margins of the fastigium of the vertex and more sulcate frontal costa; antennæ testaceous at base, beyond fusco-testaceous, 
annulate with fuscous. Pronotum robust, generally uniformly testaceous or cinereo-testaceous, rarely longitudinally striped with fuscous, and then the lower part of the head and lateral lobes are pallid; median carina distinct, percurrent, though the prozona, especially in the female, has a prominent median tuberculous swelling; lateral carinæ sharp and pronounced, even distinct on the prozona; disk of metazona generally plane, sometimes feebly rounded, densely punctate, the process obtusangulate in both sexes; lateral lobes terminating behind in an inferior pointed process, as in T.pacifica, but placed more completely at posterior margin. Tegmina, as in $T$. pacifica, but with the markings less pronounced, sometimes almost wholly wanting; hind wings feebly washed with citron in basal half, beyond hyaline, but with the apical veins and cross-veins fuscous (more deeply than in $T$. pacifica) and generally with feeble remains of a transverse mesial fuscous band like that of T. pacifica, but never continuous and generally altogether confined to the infuscation of some but not all of the veins and cross-veins of that region, and rarely shows the added infumation of some of the cells. Hind femora and tibiæ as in $T$. pacifica, the former quite as heavily marked.

Length of body, of, $28 \mathrm{~mm}$., $q, 35 \mathrm{~mm}$.; antennæ, to, $15 \mathrm{~mm}$., $q$, I $3.5 \mathrm{~mm}$.; tegmina, of, $26.75 \mathrm{~mm}$., + , 3 I. $5 \mathrm{~mm}$.; hind femora, t, I 5.5 mm., $q, 18.5 \mathrm{~mm}$.

6 f, 6 q. Ceres, Cal., Aug. I 7. A. P. Morse.

This species differs from $T$. pacifica by its more widely angled pronotal process, robuster and more angulate pronotum, the protuberance of the prozonal disk, and the almost complete, sometimes complete, absence of a band on the hind wings.

Dichopetala brevicauda, sp. nov.

Pale testaceous, the upper surface of head and pronotum tinged with flavous, which terminates on the posterior part of the pronotum at a rectangular bent line of reddish points, its angle at the posterior margin; lateral lobes obscurely marked with fuscous. Pronotum constricted just behind the front margin, emarginate posteriorly next the lower margin of the tegmina; these are testaceous, overlapping, about as long as broad, not truncate, but angulate. All the legs, but especially the hind pair, very long uniform testaceous. Ovipositor no longer than the pronotum, both margins serrate on distal half, besides which the sides of both valves of the same portion bristle with raised rufofuscous serrations, arranged linearly and gradually fading baseward. 
Length of body, $15 \mathrm{~mm}$; antennæ, $43 \mathrm{~mm}$.; pronotum, $4 \mathrm{~mm}$.; fore femora, $9 \mathrm{~mm}$.; hind femora, $22 \mathrm{~mm}$.; ovipositor, $4 \mathrm{~mm}$.

I $q$. Cahon Pass, Cal., July i 8. A. P. Morse.

This species differs distinctly from the species heretofore known in the brevity of the ovipositor, and the overlapping of the female tegmina. Arethea consuetipes, sp. nov.

Green, the pronotum sometimes testaceous, the basal half of the male tympanum testaceous, but without other markings. Tegmina just surpassing the hind femora, the radial vein sending five or six branches to the posterior margin; tympanum of male tegmina produced, lanceolate, as long behind the transverse vein as in front of it, rounded at tip ; legs shorter than common in the genus, the fore and middle femora rectangularly produced at tip.

Length of body, $16 \mathrm{~mm}$; pronotum, $4.75 \mathrm{~mm}$; tegmina, $25 \mathrm{~mm}$; wings, $29.5 \mathrm{~mm}$; hind femora, $21 \mathrm{~mm}$.

2 of. Indio, Cal., July 9. A. P. Morse.

This species differs markedly from the others in the relative brevity of the hind legs. The pronotum lacks the selliform aspect found in the other species, and this species should perhaps be generically distinguished from them.

Clinopleura flavomarginata, sp. nov.

Testaceous or fusco-testaceous, marked and sculptured quite as in C. melanopleura, but with the infuscation of the lateral lobes of the pronotum either wanting or much less pronounced, and the lateral carinæ of the pronotum, if anything, less distant. The legs, and especially the hind legs, are longer (the hind femora longer than the body), and the anal appendages of the male differ in that the cerci have a much shorter incurved apical hook, much shorter than the body of the cerci themselves, and the infragenital plate is apically truncate and not emarginate.

Length of body, of, $23 \mathrm{~mm}$.,,$+ 25.5 \mathrm{~mm}$.; pronotum, fo $q, 6.75$ $\mathrm{mm}$.; hind femora, of, $25.5 \mathrm{~mm}$, \&, $26.5 \mathrm{~mm}$.; ovipositor, $19 \mathrm{~mm}$.

5 t, 6 q. Ahwanee, Aug. 15; Ceres, Aug. 17; and Raymond, Cal., Aug. I6; A. P. Morse. Calaveras, Cal.; Riley. Other specimens of this species are in the U. S. National Museum.

Specimens of $C$. melanopleura were taken by Mr. Morse at Tehachapi, Cal., Aug. 3 . 


\section{$2 \mathrm{BHL}$ Biodiversity Heritage Library}

Scudder, Samuel Hubbard. 1900. "New or little Known Californian

Orthoptera." The Canadian entomologist 32, 329-332.

https://doi.org/10.4039/Ent32329-11.

View This Item Online: https://www.biodiversitylibrary.org/item/22161

DOI: https://doi.org/10.4039/Ent32329-11

Permalink: https://www.biodiversitylibrary.org/partpdf/1261

\section{Holding Institution}

MBLWHOI Library

Sponsored by

MBLWHOI Library

\section{Copyright \& Reuse}

Copyright Status: NOT_IN_COPYRIGHT

This document was created from content at the Biodiversity Heritage Library, the world's largest open access digital library for biodiversity literature and archives. Visit BHL at https://www.biodiversitylibrary.org. 